\title{
Tsukamurella soli sp. nov., isolated from soil
}

Correspondence
Soon-Wo Kwon
swkwon@rda.go.kr

\section{Hang-Yeon Weon, ${ }^{1}$ Seung-Hee Yoo, ${ }^{1}$ Rangasamy Anandham, ${ }^{2}$ Peter Schumann, ${ }^{3}$ Reiner M. Kroppenstedt, ${ }^{3}$ Soon-Wo Kwon ${ }^{1}$ and Erko Stackebrandt ${ }^{3}$}

\author{
${ }^{1}$ Korean Agricultural Culture Collection (KACC), National Agrobiodiversity Center, \\ Republic of Korea \\ ${ }^{2}$ Organic Agriculture Division, National Academy of Agricultural Science, Rural Development \\ Administration (RDA), Suwon 441-707, Republic of Korea \\ ${ }^{3} \mathrm{DSMZ}$ - Deutsche Sammlung von Mikroorganismen und Zellkulturen GmbH, Inhoffenstraße 7b, \\ 38124 Braunschweig, Germany
}

\begin{abstract}
A Gram-positive, rod-shaped, catalase-positive, oxidase-negative, white-coloured bacterium, designated strain JS18 $-1^{\top}$, was isolated from a soil sample collected from Halla mountain, Jeju island, Korea. 16S rRNA gene sequence analysis revealed that the strain was most closely related to members of the genus Tsukamurella with levels of sequence similarity of 95.4-96.5\%. Strain JS18 $-1^{\top}$ shared highest $16 \mathrm{~S}$ rRNA gene sequence similarity with Tsukamurella strandjordii DSM $44573^{\top}(96.5 \%)$, Tsukamurella carboxydivorans $\mathrm{Y}^{\top}{ }^{\top}(96.4 \%)$ and Tsukamurella tyrosinosolvens DSM $44234^{\top}(96.4 \%)$. The $\mathrm{G}+\mathrm{C}$ content of the total DNA of strain JS18-1 ${ }^{\top}$ was $70 \mathrm{~mol} \%$. The cell-wall peptidoglycan type was $\mathrm{A} 1 \gamma$ and mycolic acids were also detected. The predominant polar lipids were diphosphatidylglycerol, phosphatidylethanolamine and phosphatidylinositol. The major quinone was menaquinone-9 (MK-9) and major cell-wall sugars were arabinose, ribose and glucose. The major fatty acids ( $>10 \%$ of the total fatty acids) were $\mathrm{C}_{16: 0}, \mathrm{C}_{18: 1} \omega 9 c, \mathrm{C}_{18: 0}$ 10-methyl and summed feature $3\left(\mathrm{C}_{16: 1} \omega 7 \mathrm{c}\right.$ and/or iso- $\left.\mathrm{C}_{15: 0} 2-\mathrm{OH}\right)$. Phylogenetic analysis based on 16S rRNA gene sequences and chemotaxonomic, biochemical and physiological characteristics indicate that strain $\mathrm{JS} 18-1^{\top}$ represents a novel species of the genus Tsukamurella, for which the name Tsukamurella soli sp. nov. is proposed. The type strain is JS18-1 ${ }^{\top}(=\mathrm{KACC}$ $20764^{\top}=$ DSM $45046^{\top}$ ).
\end{abstract}

The genus Tsukamurella was proposed by Collins et al. (1988), the type species being Tsukamurella paurometabola. At the time of writing, the genus comprises 10 recognized species. T. paurometabola (Collins et al., 1988), T. inchonensis (Yassin et al., 1995), T. pulmonis (Yassin et al., 1996), T. tyrosinosolvens (Yassin et al., 1997) and T. strandjordii (Kattar et al., 2001) were recovered from clinical specimens. T. spumae (Nam et al., 2003), T. sunchonensis (Seong et al., 2003), T. pseudospumae (Nam et al., 2004), T. spongiae (Olson et al., 2007) and T. carboxydivorans (Park et al., 2009) were isolated from activated sludge, deep-water marine sponge and soil. Members of the genus Tsukamurella have been characterized based on the presence of mycolic acids, menaquinone- 9 and A1 $\gamma$-type peptidoglycan. Phylogenetically, the genus is closely related to the genus Dietzia. During the course of a study on cultivable bacterial

The GenBank/EMBL/DDBJ accession number for the 16S rRNA gene sequence of strain JS18-1 $1^{\top}$ is FJ917743.

A table showing differential phenotypic characteristics between strain $\mathrm{JS} 18-1^{\top}$ and the type strains of closely related species of the genus Tsukamurella is available with the online version of this paper. communities of forest soils of Halla mountain, Jeju island, Republic of Korea, a novel strain, designated JS18- ${ }^{\mathrm{T}}$, was isolated by the spread-plate technique on R2A (Difco) agar after incubation at $30{ }^{\circ} \mathrm{C}$ for 7 days. The purified strain was routinely cultivated and maintained on R2A medium. The aim of the present study was to elucidate the taxonomic position of strain JS18- $1^{\mathrm{T}}$ by using a polyphasic approach.

Cell morphology was observed by light microscopy (Axio; Zeiss). The effects of various $\mathrm{NaCl}$ concentrations $(0,1,2,3$, 4 and $5 \%, \mathrm{w} / \mathrm{v}), \mathrm{pH}(4.0-10.0$, at intervals of $1.0 \mathrm{pH}$ units $)$ and temperature $\left(5-45^{\circ} \mathrm{C}\right.$, at intervals of $\left.5{ }^{\circ} \mathrm{C}\right)$ on growth of strain JS18-1 ${ }^{\mathrm{T}}$ were investigated in R2A medium. Gram staining, catalase and oxidase activities, and hydrolysis of carboxymethylcellulose (CMC), casein, chitin, DNA, hypoxanthine, pectin, starch, Tween 80 , tyrosine and xanthine were tested according to Smibert \& Krieg (1994). The ability of the strain to grow on various substrates as sole carbon source was checked by using the basal medium of Boiron et al. (1993) and the methods employed by Nam et al. (2003, 2004). In addition, various physiological and biochemical 
properties were determined by using the API ZYM, API 20NE and API ID 32GN (bioMérieux) systems. Tests in these commercial systems were generally performed according to the manufacturer's instructions. Strain JS18- $1^{\mathrm{T}}$ was able to grow on R2A agar, nutrient agar (Difco) and trypticase soy agar (Difco), but not on MacConkey agar (Difco). Cells of strain $\mathrm{JS} 18-1^{\mathrm{T}}$ were Gram-positive, rod-shaped, non-spore-forming, catalasepositive and oxidase-negative. Colonies were white, dry and matt with irregular spreading margins and did not form capsules or aerial hyphae. Comparisons of the phenotypic characteristics of strain JS18- $1^{\mathrm{T}}$ and the type strains of closely related species of the genus Tsukamurella are presented in Table 1 and Supplementary Table S1 (available in IJSEM Online).

Chemotaxonomic studies were conducted with freezedried cells after cultivation in R2A medium for 2 days at $30{ }^{\circ} \mathrm{C}$. Analysis of the peptidoglycan was performed according to the procedure described by Schleifer \&
Kandler (1972). Polar lipids were extracted and then examined by two-dimensional TLC (Minnikin et al., 1984). Quinones were isolated by using the method of Minnikin et al. (1984) and were then separated by HPLC. Analysis of whole-cell sugars was conducted according to the method of Staneck \& Roberts (1974). The presence of mycolic acids was examined by using the method described by Minnikin et al. (1975). Cellular fatty acid methyl esters were prepared from cells grown in TSA medium for 2 days at $30{ }^{\circ} \mathrm{C}$, and were analysed by GC according to the instructions of the Microbial Identification System (MIDI). The G+C content of the DNA was determined as described by Mesbah et al. (1989) by using a reversed-phase column (Supelcosil LC-18 S; Supelco). The peptidoglycan type of strain JS18-1 ${ }^{\mathrm{T}}$ was A1 $\gamma$ based on directly cross-linked mesodiaminopimelic acid. Diphosphatidylglycerol, phosphatidylethanolamine and phosphatidylinositol were the major polar lipids. Strain JS18- $1^{\mathrm{T}}$ had a menaquinone pattern consisting of MK-9, MK-8 and MK-10, with MK-9 as the major component. Major cell-wall sugars were arabinose,

Table 1. Phenotypic properties that distinguish strain $J S 18-1^{\top}$ from the type strains of recognized species of the genus Tsukamurella

Strains: 1, JS18-1 ${ }^{\mathrm{T}}$; 2, T. carboxydivorans $\mathrm{Y}^{\mathrm{T}}$ (data from Park et al., 2009); 3, T. inchonensis IMMIB D-771 ${ }^{\mathrm{T}}$ (Yassin et al., 1995; Nam et al., 2003); 4, T. paurometabola DSM 20162 ${ }^{\mathrm{T}}$ (Collins et al., 1988; Olson et al., 2007); 5, T. pseudospumae N1176 ${ }^{\mathrm{T}}$ (Nam et al., 2003, 2004); 6, T. pulmonis IMMIB D-1321 ${ }^{\mathrm{T}}$ (Yassin et al., 1996; Park et al., 2009); 7, T. spongiae $\mathrm{K} 362^{\mathrm{T}}$ (Olson et al., 2007); 8, T. spumae N1171 ${ }^{\mathrm{T}}$ (Nam et al., 2003); 9, T. strandjordii DSM $44573^{\mathrm{T}}$ (Kattar et al., 2001; Park et al., 2009); 10, T. sunchonensis SCNU5 ${ }^{\mathrm{T}}$ (Seong et al., 2003); 11, T. tyrosinosolvens DSM 44344 ${ }^{\mathrm{T}}$ (Yassin et al., 1997; Park et al., 2009). +, Positive; -, negative; ND, not determined.

\begin{tabular}{|c|c|c|c|c|c|c|c|c|c|c|c|}
\hline Characteristic & 1 & 2 & 3 & 4 & 5 & 6 & 7 & 8 & 9 & 10 & 11 \\
\hline Colony colour & White & $\begin{array}{l}\text { White, } \\
\text { cream }\end{array}$ & $\begin{array}{l}\text { White, } \\
\text { cream }\end{array}$ & $\begin{array}{l}\text { White, } \\
\text { cream }\end{array}$ & Orange, red & $\begin{array}{l}\text { White, } \\
\text { cream }\end{array}$ & $\begin{array}{l}\text { White, } \\
\text { cream }\end{array}$ & Orange, red & $\begin{array}{l}\text { White, } \\
\text { cream }\end{array}$ & Orange & $\begin{array}{l}\text { White, } \\
\text { cream }\end{array}$ \\
\hline Growth at $10{ }^{\circ} \mathrm{C}$ & + & - & - & + & + & - & - & - & - & - & - \\
\hline \multicolumn{12}{|l|}{ Assimilation of: } \\
\hline$(+)$-D-Arabinose & - & + & + & - & + & + & - & - & - & - & + \\
\hline$(+)$-L-Arabinose & - & + & - & - & + & + & + & + & - & - & + \\
\hline$(+)$-D-Arabitol & + & + & - & - & + & + & + & + & + & $\mathrm{ND}$ & + \\
\hline$(+)$-Cellobiose & - & + & - & - & - & + & + & - & - & ND & + \\
\hline Dulcitol & - & + & - & - & - & + & - & + & - & - & + \\
\hline meso-Erythritol & - & + & - & - & - & + & - & + & - & - & + \\
\hline$(+)$-D-Fructose & + & + & - & + & + & + & + & + & - & + & + \\
\hline$(+)$-Maltose & - & + & + & - & + & + & - & + & - & + & + \\
\hline (-)-D-Mannitol & + & + & + & + & - & - & + & + & + & + & + \\
\hline$(+)$-Melezitose & - & + & + & - & + & - & + & + & - & + & + \\
\hline$(+)$-Melibiose & - & + & + & + & - & + & + & + & + & - & + \\
\hline$(-)$-D-Ribose & + & + & + & + & + & + & + & + & - & $\mathrm{ND}$ & + \\
\hline$(+)$-D-Salicin & + & + & + & + & - & + & + & - & + & ND & + \\
\hline$(-)$-D-Sorbitol & + & + & + & - & - & - & + & + & + & ND & + \\
\hline \multicolumn{12}{|l|}{ Hydrolysis of: } \\
\hline Aesculin & + & - & + & ND & + & + & $\mathrm{ND}$ & - & - & + & + \\
\hline Casein & - & + & - & - & $\mathrm{ND}$ & - & $\mathrm{ND}$ & $\mathrm{ND}$ & - & - & - \\
\hline Hypoxanthine & - & + & + & $\mathrm{ND}$ & + & + & $\mathrm{ND}$ & + & - & + & + \\
\hline Tyrosine & + & + & - & - & + & - & $\mathrm{ND}$ & + & - & + & + \\
\hline Urea & + & + & + & + & - & + & ND & - & + & - & - \\
\hline Xanthine & - & + & - & - & - & - & $\mathrm{ND}$ & - & - & - & - \\
\hline
\end{tabular}


ribose and glucose; a minor amount of galactose was also detected. The major fatty acids ( $>10 \%$ of the total) were $\mathrm{C}_{16: 0}(28.1 \%), \mathrm{C}_{18: 1} \omega 9 c(24.7 \%), \mathrm{C}_{18: 0} 10$-methyl $(12.9 \%)$ and summed feature $3\left(\mathrm{C}_{16: 1} \omega 7 c\right.$ and/or iso- $\mathrm{C}_{15: 0}$ $2-\mathrm{OH} ; 10.6 \%)$; minor components were $\mathrm{C}_{14: 0}(5.1 \%)$, $\mathrm{C}_{17: 1} \omega 8 c(3.7 \%), \mathrm{C}_{17: 0}(3.7 \%), \mathrm{C}_{21: 1} \omega 9 c(2.6 \%)$, summed feature $6\left(\mathrm{C}_{19: 1} \omega 9 c\right.$ and/or $\left.\mathrm{C}_{19: 1} \omega 11 c, 1.7 \%\right)$ and $\mathrm{C}_{18: 0}$ $(1.1 \%)$ (Table 2). The DNA G +C content of strain JS18-1 $1^{\mathrm{T}}$ was $70 \mathrm{~mol} \%$.

The 16S rRNA gene was amplified by colony PCR by using the primers fD1 and rP2 (Weisburg et al., 1991) and the entire PCR fragment was directly sequenced (Hiraishi, 1992). Levels of sequence similarity were calculated by using the EzTaxon server (http://www.eztaxon.org/; Chun et al., 2007). An alignment of $16 \mathrm{~S}$ rRNA gene sequences was performed with the CLUSTAL W program (Thompson et al., 1994), and phylogenetic analysis was performed by using MEGA version 3.1 (Kumar et al., 2004). Phylogenetic dendrograms were constructed based on the neighbour-joining (Saitou \& Nei, 1987) and maximum-parsimony (Fitch, 1971) methods with bootstrap values based on 1000 replications. Strain JS18-1 $1^{\mathrm{T}}$ exhibited levels of 16S rRNA gene sequence similarity of 95.4-
$96.5 \%$ to the type strains of recognized species of the genus Tsukamurella. It shared highest $16 \mathrm{~S}$ rRNA gene sequence similarity with $T$. strandjordii DSM $44573^{\mathrm{T}}(96.5 \%), T$. carboxydivorans $\mathrm{Y}^{\mathrm{T}}(96.4 \%)$ and T. tyrosinosolvens DSM $44234^{\mathrm{T}}(96.4 \%)$. In the neighbour-joining tree, strain JS18-1 ${ }^{\mathrm{T}}$ formed a separate phylogenetic lineage from members of the genus Tsukamurella that was supported by a high bootstrap value (99\%) (Fig. 1); this result was also found in the maximum-parsimony tree.

The presence of mycolic acids, DNA G $+\mathrm{C}$ content (70 mol\%), MK-9 as the predominant quinone, Al $\gamma$-type peptidoglycan and $\mathrm{C}_{16: 0}, \mathrm{C}_{18: 1} \omega 9 c, \mathrm{C}_{18: 0}$ 10-methyl and summed feature 3 as major fatty acids supported the classification of strain $\mathrm{JS} 18-1^{\mathrm{T}}$ within the genus Tsukamurella. However, the novel strain could be differentiated from recognized species of the genus Tsukamurella based on levels of $16 \mathrm{~S}$ rRNA gene sequence similarity, phylogenetic analysis and several phenotypic characteristics (Table 1 and Supplementary Table S1). Strain JS18- $1^{\mathrm{T}}$ is therefore considered to represent a novel species of the genus Tsukamurella, for which the name Tsukamurella soli sp. nov. is proposed.

Table 2. Comparison between the fatty acid compositions (\%) of strain JS18-1 ${ }^{\top}$ and those of members of the genus Tsukamurella Strains: 1, JS18-1 $1^{\mathrm{T}}$; 2, T. carboxydivorans $\mathrm{Y}^{\mathrm{T}}$ (data from the present study); 3, T. inchonensis IMMIB D-771 ${ }^{\mathrm{T}}$ (Kattar et al., 2001); 4, T. paurometabola DSM $20162^{\mathrm{T}}$ (Kattar et al., 2001); 5, T. pulmonis IMMIB D-1321 ${ }^{\mathrm{T}}$ (Nam et al., 2003); 6, T. spongiae K362 ${ }^{\mathrm{T}}$ (Olson et al., 2007); 7 ,

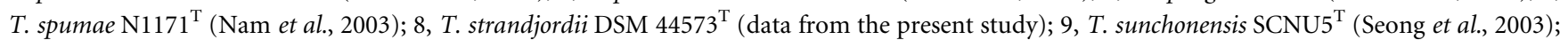
10, T. tyrosinosolvens DSM $44344^{\mathrm{T}}$ (data from the present study). -, Less than $1 \%$ or not detected.

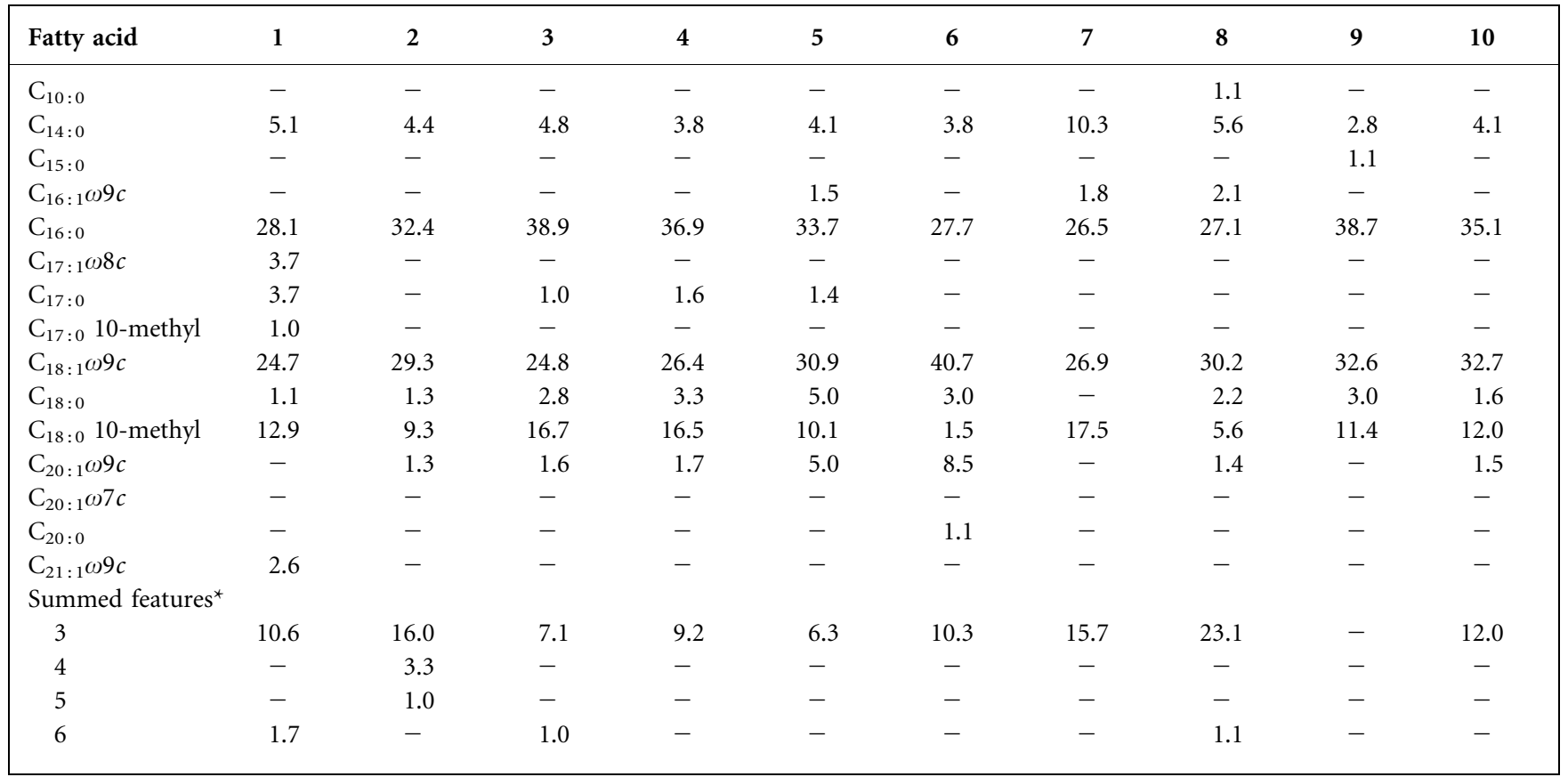

*Summed features are groups of two or three fatty acids that cannot be separated by GLC with the MIDI system. Summed feature 3 comprises $\mathrm{C}_{16: 1} \omega 7 c$ and/or iso- $\mathrm{C}_{15: 0} 2-\mathrm{OH}$; summed feature 4 comprises iso- $\mathrm{C}_{17: 1} \mathrm{I}$ and/or anteiso- $\mathrm{C}_{17: 1} \mathrm{~B}$; summed feature 5 comprises $\mathrm{C}_{18: 2} \omega 6,9 c$ and/or anteiso- $\mathrm{C}_{18: 0}$; summed feature 6 comprises $\mathrm{C}_{19: 1} \omega 9 \mathrm{c}$ and/or $\mathrm{C}_{19: 1} \omega 11 \mathrm{c}$. 


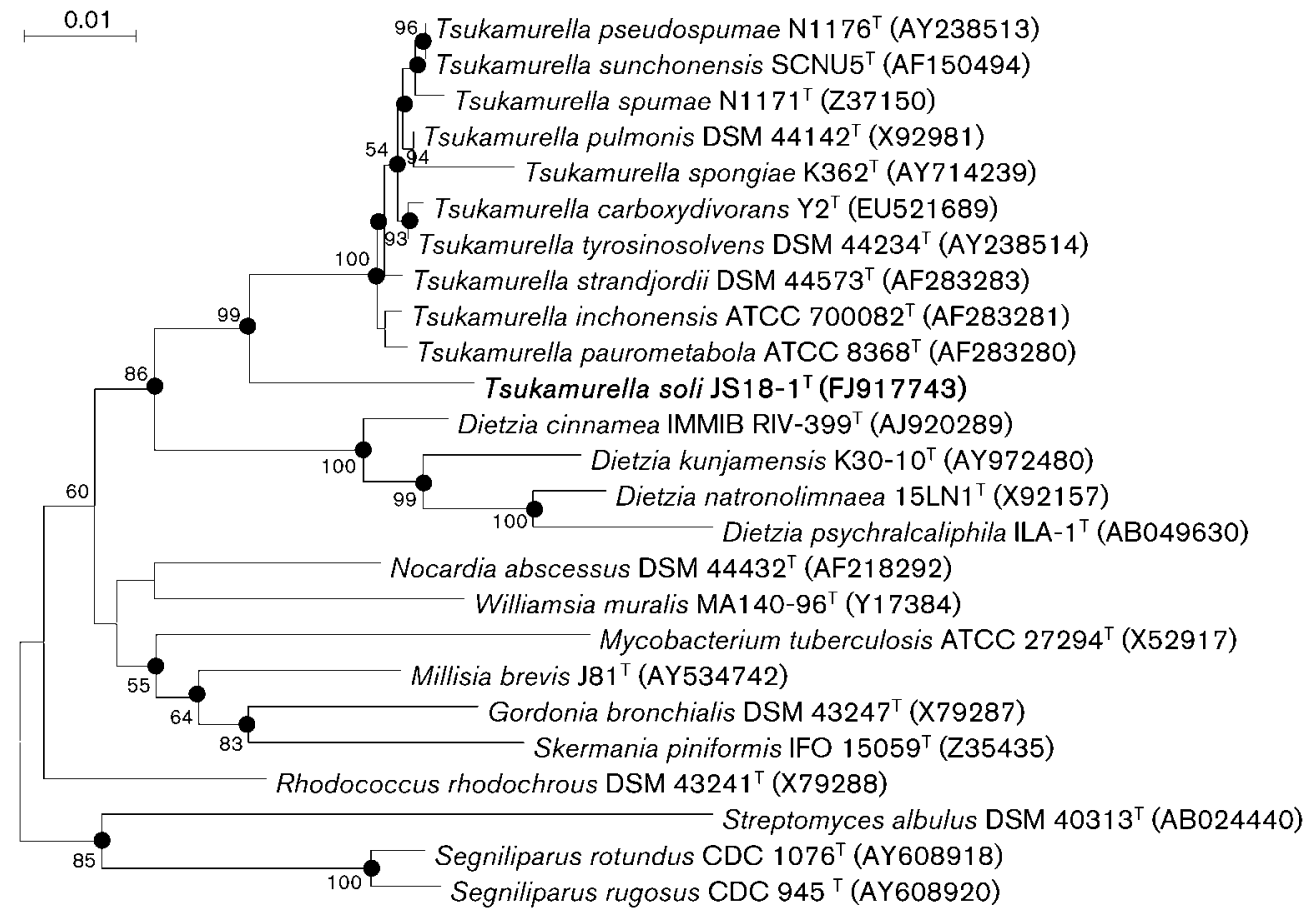

Fig. 1. Neighbour-joining phylogenetic tree based on $16 \mathrm{~S}$ rRNA gene sequences showing the position of strain $\mathrm{JS} 18-1^{\top}$ with respect to the type strains of closely related species. Numbers at nodes indicate bootstrap values, expressed as percentages of 1000 replications; only values $>50 \%$ are shown. Filled circles indicate that the corresponding branches were also recovered in the maximum-parsimony tree. Bar, 0.01 changes per nucleotide position.

\section{Description of Tsukamurella soli sp. nov.}

Tsukamurella soli (so'li. L. neut. gen. n. soli of soil, the source of the type strain).

Cells are Gram-positive, rod-shaped $(0.9-1.0 \mu \mathrm{m}$ in length and $2.3-6.0 \mu \mathrm{m}$ in width), catalase-positive and oxidasenegative. Colonies on R2A medium are white, dry and matt with irregular spreading margins. Growth occurs at $10-35{ }^{\circ} \mathrm{C}$ and at $\mathrm{pH} 4.0-9.0$. The optimum temperature and $\mathrm{pH}$ for growth are $30{ }^{\circ} \mathrm{C}$ and 7.0. Tolerates $\mathrm{NaCl}$ concentrations up to $3.0 \%(\mathrm{w} / \mathrm{v})$. Hydrolyses Tween 80 and tyrosine, but not casein, chitin, CMC, DNA, hypoxanthine, pectin, starch or xanthine. Positive for urease and aesculin hydrolysis, but negative for nitrate reduction, indole production, glucose fermentation, arginine dihydrolase and $\beta$-galactosidase (API 20NE). Assimilates D-glucose, D-mannitol, $\mathrm{N}$-acetylglucosamine, trisodium citrate, D-ribose, inositol, sucrose, sodium acetate, lactic acid, L-alanine, glycogen, salicin, D-sorbitol, propionic acid, valeric acid and 3-hydroxybutyric acid, but not L-arabinose, D-mannose, maltose, potassium gluconate, capric acid, adipic acid, malic acid, phenylacetic acid, Lrhamnose, itaconic acid, suberic acid, sodium malonate, potassium 5-ketogluconate, 3-hydroxybenzoic acid, L-serine, melibiose, L-fucose, L-histidine, potassium 2-ketogluconate, 4-hydroxybenzoic acid or L-proline (API 20NE and API ID $32 \mathrm{GN}$ ). Positive for alkaline phosphatase, esterase lipase (C8), leucine arylamidase, acid phosphatase, naphthol-AS-BIphosphohydrolase, $\alpha$-glucosidase and $\beta$-glucosidase, weakly positive for esterase (C4) and lipase (C14), and negative for valine arylamidase, cystine arylamidase, trypsin, $\alpha$-chymotrypsin, $\alpha$-galactosidase, $\beta$-galactosidase, $\beta$-glucuronidase, $N$-acetyl- $\beta$-glucosaminidase, $\alpha$-mannosidase and $\alpha$-fucosidase (API ZYM). The cell wall contains Al $\gamma$-type peptidoglycan based on directly cross-linked meso-diaminopimelic acid. Major cell-wall sugars are arabinose, ribose and glucose; a minor amount of galactose is also present. Polar lipids are diphosphatidylglycerol, phosphatidylethanolamine and phosphatidylinositol. The predominant menaquinone is MK-9; minor amounts of MK-8 and MK-10 are also present. The major fatty acids $\left(>10 \%\right.$ of the total) are $\mathrm{C}_{16: 0}$, $\mathrm{C}_{18: 1} \omega 9 c, \mathrm{C}_{18: 0} 10$-methyl and summed feature $3\left(\mathrm{C}_{16: 1} \omega 7 c\right.$ and/or iso- $\mathrm{C}_{15: 0} 2-\mathrm{OH}$ ).

The type strain, JS18 $-1^{\mathrm{T}}\left(=\right.$ KACC $20764^{\mathrm{T}}=$ DSM $\left.45046^{\mathrm{T}}\right)$, was isolated from a soil sample collected from Halla mountain, Jeju island, Republic of Korea. The DNA G + C content of the type strain is $70 \mathrm{~mol} \%$.

\section{Acknowledgements}

This work was supported by the National Academy of Agricultural Science (NAAS), Rural Development Administration, Republic of Korea. 


\section{References}

Boiron, P., Provost, F. \& Dupont, B. (1993). Technical protocols. In Méthodes de Laboratoire pour le Diagnostic de la Nocardiose, pp. 107126. Edited by Institut Pasteur. Paris: Institut Pasteur.

Chun, J., Lee, J. H., Jung, Y., Kim, M., Kim, S., Kim, B. K. \& Lim, Y. W. (2007). EzTaxon: a web-based tool for the identification of prokaryotes based on $16 \mathrm{~S}$ ribosomal RNA gene sequences. Int J Syst Evol Microbiol 57, 2259-2261.

Collins, M. D., Smida, J., Dorsch, M. \& Stackebrandt, E. (1988). Tsukamurella gen. nov., harboring Corynebacterium paurometabolum and Rhodococcus aurantiacus. Int J Syst Bacteriol 38, 385-391.

Fitch, W. M. (1971). Toward defining the course of evolution: minimum change for a specific tree topology. Syst Zool 20, 406-416.

Hiraishi, A. (1992). Direct automated sequencing of $16 \mathrm{~S}$ rDNA amplified by polymerase chain reaction from bacterial cultures without DNA purification. Lett Appl Microbiol 15, 210-213.

Kattar, M. M., Cookson, B. T., Carlson, L. D., Stiglich, S. K., Schwartz, M. A., Nguyen, T. T., Daza, R., Wallis, C. K., Yarfitz, S. L. \& Coyle, M. B. (2001). Tsukamurella strandjordae sp. nov., a proposed new species causing sepsis. J Clin Microbiol 39, 1467-1476.

Kumar, S., Tamura, K. \& Nei, M. (2004). MEGA3: integrated software for molecular evolutionary genetics analysis and sequence alignment. Brief Bioinform 5, 150-163.

Mesbah, M., Premachandran, U. \& Whitman, W. B. (1989). Precise measurement of the $\mathrm{G}+\mathrm{C}$ content of deoxyribonucleic acid by highperformance liquid chromatography. Int J Syst Bacteriol 39, 159-167.

Minnikin, D. E., Alshamaony, L. \& Goodfellow, M. (1975). Differentiation of Mycobacterium, Nocardia, and related taxa by thin layer chromatographic analysis of whole-cell methanolysates. J Gen Microbiol 88, 200-204.

Minnikin, D. E., O'Donnell, A. G., Goodfellow, M., Alderson, G., Athalye, M., Schaal, A. \& Parlett, J. H. (1984). An integrated procedure for the extraction of bacterial isoprenoid quinones and polar lipids. J Microbiol Methods 2, 233-241.

Nam, S. W., Chun, J., Kim, S., Kim, W., Zakrzewska-Czerwinska, J. \& Goodfellow, M. (2003). Tsukamurella spumae sp. nov., a novel actinomycete associated with foaming in activated sludge plants. Syst Appl Microbiol 26, 367-375.

Nam, S. W., Kim, W., Chun, J. \& Goodfellow, M. (2004). Tsukamurella pseudospumae sp. nov., a novel actinomycete isolated from activated sludge foam. Int J Syst Evol Microbiol 54, 1209-1212.
Olson, J. B., Harmody, D. K., Bej, A. K. \& McCarthy, P. J. (2007). Tsukamurella spongiae sp. nov., a novel actinomycete isolated from a deep-water marine sponge. Int J Syst Evol Microbiol 57, 14781481.

Park, S. W., Kim, S. M., Park, S. T. \& Kim, Y. M. (2009). Tsukamurella carboxydivorans sp. nov., a carbon monoxide-oxidizing actinomycete. Int J Syst Evol Microbiol 59, 1541-1544.

Saitou, N. \& Nei, M. (1987). The neighbor-joining method: a new method for reconstructing phylogenetic trees. Mol Biol Evol 4, 406425.

Sasser, M. (1990). Identification of bacteria by gas chromatography of cellular fatty acids, MIDI Technical Note 101. Newark, DE: MIDI Inc.

Schleifer, K. H. \& Kandler, O. (1972). Peptidoglycan types of bacterial cell walls and their taxonomic implications. Bacteriol Rev 36, 407-477.

Seong, C. N., Kim, Y. S., Baik, K. S., Choi, S. K., Kim, M. B., Kim, S. B. \& Goodfellow, M. (2003). Tsukamurella sunchonensis sp. nov., a bacterium associated with foam in activated sludge. J Microbiol 41, 83-88.

Smibert, R. M. \& Krieg, N. R. (1994). Phenotypic characterization. In Methods for General and Molecular Bacteriology, pp. 607-654. Edited by P. Gerhardt, R. G. E. Murray, W. A. Wood \& N. R. Krieg. Washington, DC: American Society for Microbiology.

Staneck, J. L. \& Roberts, G. D. (1974). Simplified approach to identification of aerobic actinomycetes by thin-layer chromatography. Appl Microbiol 28, 226-231.

Thompson, J. D., Higgins, D. G. \& Gibson, T. J. (1994). ClUSTAL W: improving the sensitivity of progressive multiple sequence alignment through sequence weighting, position-specific gap penalties and weight matrix choice. Nucleic Acids Res 22, 4673-4680.

Weisburg, W. G., Barns, S. M., Pelletier, D. A. \& Lane, D. J. (1991). 16 S ribosomal DNA amplification for phylogenetic study. J Bacteriol 173, 697-703.

Yassin, A. F., Rainey, F. A., Brzezinka, H., Burghardt, J., Lee, H. J. \& Schaal, K. P. (1995). Tsukamurella inchonensis sp. nov. Int J Syst Bacteriol 45, 522-527.

Yassin, A. F., Rainey, F. A., Brzezinka, H., Burghardt, J., Rifai, M., Seifert, P., Feldmann, K. \& Schaal, K. P. (1996). Tsukamurella pulmonis sp. nov. Int J Syst Bacteriol 46, 429-436.

Yassin, A. F., Rainey, F. A., Burghardt, J., Brzezinka, H., Schmitt, S., Seifert, P., Zimmermann, O., Mauch, H., Gierth, D. \& other authors (1997). Tsukamurella tyrosinosolvens sp. nov. Int J Syst Bacteriol 47, 607-614. 